\title{
DeVEloping A PREROGATIVE THEORY FOR THE AUTHORITY OF THE
}

\section{CHANCERY: THE FRENCH CONNECTION}

\author{
Ian Williams
}

The controversy involving the English Chancery in 1616 is well-known. ${ }^{1}$ A conflict over Chancery intervening after judgment at law led to debates about the propriety

\footnotetext{
- Lecturer, Faculty of Laws, UCL. My thanks to Adolfo Giuliani, my LLM seminar group in the Historical Development of the Common Law and participants in the 2013 British Legal History Conference for their assistance and comments. I have used the following abbreviations: BL MS Add (British Library Additional Manuscript); BL MS Egerton (British Library Egerton Manuscript); BL MS Harg (British Library Hargrave Manuscript); BL MS Harl (British Library Harley Manuscript). References to William Lambarde's Archeion are to C. H. Mcllwain and P. L. Ward (eds.), Archeion or, a
} Discourse upon the High Courts of Justice in England by William Lambarde (Cambridge MA: Harvard University Press, 1957). Quotations from Bodin's République are taken from K. D. McRae (ed.), The Six Bookes of a Commonweal (New York: Arno Press, 1979). This version of the text is the 1606 translation of the République by Richard Knolles, based on both the original French (1576) and the 1586 Latin text, which were substantially different (see McRae 'Introduction' in Bodin, Six Bookes, pp. A28-A38). I have compared the Knolles text to the third French printing of 1578 (J. Bodin, Les Six Livres de la Republique (Paris: Jacques du Puy, 1578)). Passages where the English translation arguably diverges from the French are noted in the footnotes, but do not affect the argument presented here.

${ }^{1}$ J. P. Dawson, 'Coke and Ellesmere Disinterred: The Attack on the Chancery in 1616' (1941-2) 36 Illinois Law Review 127; J. H. Baker, 'The Common Lawyers and the Chancery: 1616' (1969) 4 Irish Jurist 368; L. A. Knafla, Law and Politics in Jacobean England (1977, Cambridge University Press), pp. 155-181. 
and legality of equitable intervention. Ultimately the king supported the Chancery and Edward Coke was dismissed as Chief Justice of the King's Bench. There are two main strands which are identified in historical discussion of the dispute. The first concerns the relationship between law and equity and the supremacy of equity. ${ }^{2}$ The second regards the dispute as part of a conflict concerning the "prerogative" courts, reflective of common law opposition to the arbitrary prerogative. ${ }^{3}$ This paper considers why the authority of the Chancery was considered to be found in the royal prerogative. ${ }^{4}$ In doing so, the paper reconsiders Elizabethan and Jacobean sources

\footnotetext{
${ }^{2}$ Eg, Baker, 'Common Lawyers'. In this paper I use 'equity' to describe the Chancery's jurisdiction which was based on the idea of epieikeia: justice which could not be provided in the regular courts by ordinary course of law. On epieikeia see J.L. Barton, 'Introduction' to T. F. T. Plucknett and J. L. Barton (eds.), St German's Doctor and Student (91 Seld. Soc., 1974), pp. xliv-li. This meaning therefore excludes the 'equity of the statute' used by the common law courts in interpreting statutes and Halliday's recent use of 'equity' in relation to the prerogative writs in the common law courts c.160o (P. Halliday, Habeas Corpus: from England to Empire (Cambridge MA: Harvard University Press, 2010), pp. 87-93).

${ }^{3}$ Eg J. S. Hart, The Rule of Law 1603-1660: Crown, Courts and Judges (Harlow: Pearson Education, 2003), p. 48.
}

${ }^{4}$ This is not to assume that the idea of a wider conflict between the common law and the prerogative is supported by the sources. For present purposes, it is sufficient to note that people interested in defending the Chancery's jurisdiction in 1616 clearly did see claims about the prerogative basis of that jurisdiction as important. 
concerning the Chancery and equity and examines the changing conceptualisation of the prerogative from the late-1570s into the Jacobean period.

The argument in this paper is that the association between the Chancery and prerogative is a result of the changing conceptualisation of the prerogative from the late-1570s as well as James I's accession to the throne. Before the 1570s, common lawyers discussed the royal prerogative as a set of prerogatives: special royal rights in relation to property law. During the reigns of Elizabeth and James this view changed: royal powers generally were the prerogative and to challenge or restrict this prerogative was to undermine the king himself. This view meant that royal intervention to provide justice came to be seen as part of the royal prerogative, and as a consequence the Chancery became intellectually tied to ideas of prerogative. In addition to setting out the evidence of the change, the paper argues that a cause of this change can be identified in the influence of the writings of Jean Bodin. Direct evidence is too limited to demonstrate that Bodin's influence was the sole cause, but a number of writings about the Chancery demonstrably made use of Bodin, albeit without citation. Bodin's ideas about sovereignty and the authority of a ruler in relation to equity came to inform views about the authority of the Chancery itself. ${ }^{5}$

\footnotetext{
5 The paper therefore also demonstrates the early influence of Bodin on English lawyers. For discussion of the influence of Bodin before the 1606 translation of the République, see G. Mosse, 'The Influence of Jean Bodin's République in English Political Thought' (1948) 5 Medievalia et Humanistica 73. The evidence from Lambarde's Archeion (see notes 52-72 below), antedates the earliest identified
} 


\section{EXPLAINING THE AUTHORITY OF THE CHANCERY BEFORE THE LATE-157OS}

At first sight, links between the Chancery and the royal prerogative seem obvious. Historically the Chancery did emerge from exercises of the royal power to do justice, a power which was accepted as a royal duty. ${ }^{6}$ However, many discussions of Chancery and equity by lawyers make no reference to any specifically royal power at all. Probably the standard early-modern work on the Chancery, Christopher St German's Doctor and Student, is entirely silent on the source of the Chancery's authority, considering only the necessity of equity. ${ }^{7}$ The same can be said about later works, such as William West's discussion of equity and the Chancery in

influence from Bodin in printed sources (Mosse, 'Influence', p. 75) by two years. Citations to Bodin's Method by English writers on history can be seen from 1575 (see J. D. Alsop, ‘William Fleetwood and Elizabethan Historical Scholarship' (1994) 25 Sixteenth Century Journal 155, p. 165).

${ }^{6}$ See, e.g., W. H. Bryson, 'Introduction' to W. H. Bryson (ed.), Cases Concerning Equity and the Courts of Equity 1550-1660 (117 Seld. Soc., 2000), vol. 1, pp. xix-xxii.

${ }^{7}$ Plucknett and Barton, St German's Doctor and Student. This is not to say that the link between the king and equity was not made by others before the reign of Elizabeth, but that legal discussion of the Chancery did not mention the monarch's role. For a seemingly non-legal reference to the prince providing epieikeia in the fifteenth century, see A. Cromartie, The Constitutionalist Revolution (Cambridge: Cambridge University Press, 2006), p. 7. 
Symbolaeography. ${ }^{8}$ If the prerogative has a role in these theories, it is not a role which is ever explained, nor is it a necessary role - the authority of the Chancery was dependent upon the need for equity, not the power of the monarch. Earlier debates about the jurisdiction of the Chancery to issue injunctions after common law judgment do not seem to have raised the issue of the link between the Chancery and the prerogative. ${ }^{9}$

$8 \mathrm{~W}$. West, The second part of Symboleography, newly corrected and amended, and very much enlarged in all the foure seuerall treatises (London: Thomas Wight, 1601), ff. 173 ${ }^{\mathrm{v}-177}$. West's discussion of equity used Hermann Vulteius' Jurisprudentia Romana (1590) (see M. R. T. Macnair, The Law of Proof in EarlyModern Equity (Berlin: Duncker \& Humblot, 1999), p. 44.

9 See J. H. Baker, The Oxford History of the Laws of England, vol. VI, 1483-1558 (Oxford: Oxford University Press, 2003), pp. 174-5 for the Henrician period. The surviving material concerning Finch v. Throgmorton (1598), which raised the same legal issue as the 1616 controversy, does not refer to the prerogative, although all but one of the surviving law reports were either written by Coke (E. Coke, The Third Part of the Institutes of the Laws of England (London: M. Flesher, 1644), p. 124; E. Coke, The Fourth Part of the Institutes of the Laws of England (London: M. Flesher, 1644), p. 86) or report Coke's references to Finch v. Throgmorton in later cases (3 Buls. 118; Cro. Jac. 344). Coke's own report of Finch v. Throgmorton (BL MS Harl. 6686, ff. 222 ${ }^{\mathrm{v}}-227$ ) does not mention the prerogative. The one report not associated with Coke (W. H. Bryson (ed.), Cases Concerning Equity and the Courts of Equity 1550-1660 (118 Seld. Soc., 2001), vol. 2, p. 441) does not mention the prerogative. Two tracts in relation to the 1598 debate do not link the Chancery and the prerogative (Henry E. Huntington Library Ellesmere Manuscripts 2920 (supporting the King's Bench) and 2986 (supporting the Chancery)). Aside from one of these tracts, the material surviving about Finch v. Throgmorton favours the common law courts, whose supporters never refer to prerogative issues. 
Nevertheless, legal historians have linked the emergence of the jurisdiction of the Chancery with the prerogative. ${ }^{10}$ The evidence of such a link is very limited, especially in terms of influencing the debates about the Chancery jurisdiction after 1600, which is when the association with the prerogative was explicit. Fortescue regarded the provision of equity as an exercise of the prince's potestas absoluta in his De Natura Legis Naturae. ${ }^{11}$ This is the only explicit evidence of an association between the Chancery and royal power in the fifteenth century. ${ }^{12}$ For purposes of considering the Chancery as a prerogative court in late-Elizabethan and Jacobean England, it should be remembered that Fortescue's De Natura was little known, if at all, to English lawyers in the sixteenth and seventeenth centuries, and none of the Elizabethan and Jacobean discussions about the Chancery even mention or allude to it. ${ }^{13}$ Fortescue's views therefore had no impact on the early-modern debates.

${ }^{10}$ See, e.g., Macnair, The Law of Proof, p. 37.

${ }^{11}$ J. Fortescue, De Natura Legis Naturae in T. Fortescue (ed.), The Works of Sir John Fortescue, Knight, Chief Justice of England and Lord Chancellor to King Henry the Sixth, 2 vols. (privately printed, 1869), vol. 1, c. 24 (Latin original at pp. 85-6, English translation at pp. 214-5).

${ }^{12}$ It is not clear when De Natura Legis Naturae was written, see R. McGerr, A Lancastrian Mirror for Princes (Bloomington IN: Indiana University Press, 2011), p. 118.

${ }^{13}$ In 1614, Edward Coke stated that he had a manuscript of 'a booke in defence of the title of king H.6.' by Fortescue ('To the Reader' in E. Coke, La Dixme Part des Reports de Sir Edw. Coke (London: Societie of Stationers, 1614), sig. diiii). In 1616, John Selden observed that Fortescue had written three books, the De Laudibus, 'his Difference between Dominium Regale and Dominium Politicum and regale, 
The only other possible link is the reference to the Chancery proceeding according to "absolute" power. This argument needs to be treated with caution. A good example can be found in a yearbook report of a Chancery case in $1469 .{ }^{14}$ Stillington C explains that there are two kinds of powers and processes, ordinary and absolute. Given that it was also recognised that the king had two types of prerogative, ordinary and and that Declaration touching the title of the Crowne'. The last two 'remaine Mss. in divers hands' ('To the Reader' in J. Fortescue, De Laudibus Legum Angliae (London: Companie of Stationers, 1616), sig. Tiiiv). De Natura was one of a series of succession tracts so could be the work referred to be Coke and Selden, but this cannot be certain (see S. B. Chrimes, 'List of Fortescue's Works' in J. Fortescue, De Laudibus Legum Anglie (Cambridge: Cambridge University Press, 1949), p. 1xxvi). Fortescue set out the idea of the dominium politicum et regale in De Natura, so De Natura could be the other work listed by Selden, but The Governance of England was also known as 'Of the difference between an absolute and limited monarchy' (Chrimes, 'List of Works', p. lxxvi). Selden did acquire a manuscript copy of the De Natura at some stage (see D. S. Berkowitz, John Selden's Formative Years: Politics and Society in EarlyModern England (Cranbury NJ: Associated University Presses, 1988), p. 313 n. 31). Selden was sent a manuscript of material by Fortescue by Thomas Allen in 1616, but according to Allen that was 'lyttle in hyt wiche is not in an olde prynte', suggesting that the manuscript consisted predominantly of $D e$ Laudibus (R. Beddard, 'Thomas Allen and John Selden and the 1616 edition of Fortescue's De Laudibus Legum Angliae' (2004) 53 The Book Collector 533, p. 541).

${ }^{14}$ (1469) YB T.9.Edw.4 f. 14 pl. 9. Macnair identifies the case as demonstrating that equity was an appeal to the 'absolute' power of the king (Macnair, The Law of Proof, p. 37), which seems to be a misreading. 
absolute, ${ }^{15}$ the link seems clear. However, the description of a power as "ordinary", as Stillington explained, simply meant that a certain order was observed: the power was exercised according to a specified procedure or rules. The description of a power as "absolute" meant that no such order was required. The distinction was well-known in medieval Europe, featuring in both theology and canon law, even entering sermon literature. ${ }^{16}$ Such an analytical model could be applied to the Chancellor; it could also be applied to different royal prerogatives, some of which were exercised according to law while some were not. The fact that the same mode of analysis could be applied to the Chancellor, the King and God did not necessarily

${ }^{15}$ The earliest reference I have found to common lawyers discussing the 'absolute' prerogative is The Case of Impositions on Cloth (1559) Dyer 165 at f. $165^{\mathrm{v}}$, where the 'absolute power' of Mary is mentioned. The general invisibility of the 'absolute' prerogative from legal sources is not surprising. Not only were exercises of the absolute prerogative not governed by law (and so unlikely to be of interest to lawyers), but sensitive matters such as the prerogative were often omitted from (printed) law reports (see J. H. Baker, 'Introduction' in J. H. Baker (ed.), Reports from the Lost Notebooks of Sir James Dyer (109 Seld. Soc., 1993), vol. 1, p. xlv). James Morice distinguishes between the king's 'absolute authoritie' and 'ordinary power in Administracion of Justice', in a context where the 'absolute authoritie' seems to be the king's prerogative (BL MS Egerton 3376, f. 27). For more discussion of Morice's reading, see notes 36-39 and 73-83 below.

${ }^{16}$ See F. Oakley, 'Jacobean Political Theology: The Absolute and Ordinary Powers of the King' (1968) 29 Journal of the History of Ideas 323. For the use of the distinction outside of the scholarly context, see F. Oakley, 'The Absolute and Ordained Power of God in Sixteenth- and Seventeenth-Century Theology' (1998) 59 Journal of the History of Ideas 437, p. 443. 
imply a causative link. The only early-modern writer who can be seen to have linked the Chancellor and the prerogative in this way is the controversial civilian John Cowell. ${ }^{17}$

The shared use of the language and idea of ordinary and absolute power does not mean that the equitable activities of the Chancery were seen as an application of the prerogative. Stillington did not draw that link, and neither did later common lawyers. William Lambarde's use of language is instructive. In the Archeion, when Lambarde refers to the "absolute" power of the prince, there is never any contrast made with "ordinary" power. ${ }^{18}$ However, when Lambarde refers to the absolute power of the Chancellor to administer equity, this is in contrast to the "ordinary" jurisdiction of the Chancery and there is no reference to the prince's absolute power. ${ }^{19}$ Ellesmere similarly distinguished between the absolute power of the Chancellor and the ordinary power of the common law judges. ${ }^{20}$ However, when

\footnotetext{
${ }_{17} \mathrm{~J}$. Cowell, The Interpreter: or Booke containing the signification of words (Cambridge: John Legate, 1607), sig. $\mathrm{N}^{\mathrm{v}}$.

${ }^{18}$ BL MS Lansd 621 ff. $78^{v}, 81$ and $83^{\vee v}$ (a letter about the Chancery from 1577) and Lambarde, Archeion, pp. 39 and 40.

19 BL MS Lansd 621 f. 79v; Lambarde, Archeion, p. 32. In the Eirenarcha, Lambarde contrasts the Chancellor's "absolute" power to "limited" power (Eirenarcha: or of the office of justices of peace (London: Thomas Wight, 1581), p. 65).

${ }^{20}$ Earl of Oxford's Case (1615) 1 Chan. Rep. 14-15.
} 
discussing the prerogative, Ellesmere insisted that all aspects of the prerogative were a species of "absolute" power. ${ }^{21}$ Finally, William West's discussion of equity mentions the Chancellor's absolute power, but never even mentions the king and his power, let alone connects the king's power with equity. ${ }^{22}$

Before the texts discussed in this paper, there are two early-modern references which directly associate the Chancery with the royal prerogative. Both are found in a collection of material on Chancery associated with William Lambarde and they may have had some influence on Lambarde's view of equity as a prerogative function, although neither is alluded to in the Archeion. ${ }^{23}$ The first is anonymous and undated. The text is entitled "Curie Cancellariae prerogativa $\& c^{\prime}$ " and explains that "The Courte of Chauncerye is the kings prerogative Royall and all other Courtes (except the Parliament) are inferior Courtes to the same for it is well knowne that the Courte of Chauncerie drawethe all manner of Accions from all other Courts as by the applicacions to his kingelie Maiestie". ${ }^{24}$ The author then explains this point: "And so

\footnotetext{
21 'A Coppie of a Wrytten Discourse by the Lord Chauncellor Elsemere Concerning the Royall Prerogative' in Knafla, Law and Politics, pp. 197-8.

${ }^{22}$ West, Symboleography, f. 177 .

${ }^{23}$ BL MS Lansd 621. On the material Lambarde compiled about the Chancery, see P. L. Ward, ‘William Lambarde’s Collections on Chancery' (1953) 7 Harvard Library Bulletin 271.

${ }^{24}$ BL MS Lansd $621 \mathrm{f}$. 18. Ward explains that the text must date from before 1573 (see Ward, 'William Lambarde's Collections', p. 289 n. 75).
} 
all other Courts have no iurisdicion to holde plea but they must receive their Originall from the Courte of Chauncerye", a point which the author substantiates by listing types of actions and repeating for each one that a writ from the Chancery would be required before a court could hear the case. Similarly, justices of assize or oyer et terminer only had jurisdiction due to commission issued by the Chancery. ${ }^{25}$ The text is not concerned with equity, and the reference to the royal prerogative at the outset is never mentioned again.

The second text is more significant. Henry, the second Lord Cromwell, "one of the lesser and seedier Elizabethan peers" was a defendant in a Chancery suit and his behaviour led the Chancery to attach him for contempt. ${ }^{26}$ Cromwell was eventually arrested, about which he complained in parliament in June 1572, raising the question whether a peer could be arrested for contempt of the Chancery. Nicholas Bacon defended the Chancery's jurisdiction and did so by associating the Chancery closely with the monarch. Bacon started from the accepted case of a peer who had showed contempt to the monarch, explaining that such a person would be subject to arrest. He then argued from analogy: disobedience to a Chancery decree is contempt of the prince and so a peer would be subject to arrest. The intellectual basis for this analogy is that "the Prince by his prerogative hath powre to order causes otherwise then the

\footnotetext{
${ }^{25}$ BL MS Lansd 621 f. $18^{v}$.

${ }^{26}$ On the proceedings see generally, M. A. R. Graves, 'Freedom of Peers from Arrest: The Case of Henry Second Lord Cromwell, 1571-1572' (1977) 21(1) AJLH 1, pp. 5-14.
} 
lawe ys \& to helpe the subiects in a cawse wherein he hath noe helpe by lawe whiche semes in reason as greate a prerogative as maie bee" ${ }^{27}$ Bacon expressly linked equity and the prerogative, a point which he reiterated in conclusion. Further arguments were made, but these did not concern equity or the prerogative. ${ }^{28}$

After consultation with the judges "and others of the Queenes Majesties learned Councell", the (self-interested) House of Lords was unconvinced and Cromwell's protection from arrest remained intact. However, the conclusion of the Lords listed reasons by which their decision could be reviewed in a future parliament, including that "there shalbee shewed sufficient matter that by the Queenes Prerogative...the persons of anie of the Lordes of Parliament in such case as this case of the Lord Cromwell is, ought to bee attached or attachable".${ }^{29}$ The inference seems to be that the House of Lords, following consultation with the common law judges, did not accept the claim that the jurisdiction of the Chancery was intimately connected with the royal prerogative, but that if the claim were substantiated, that would be a reason to allow attachment of peers. Elizabeth herself was also usually sensitive to encroachment on her prerogative, so the absence of royal concern about the case

\footnotetext{
${ }^{27}$ BL MS Lansd 621, f. 86.

${ }^{28}$ These arguments were based on custom, that otherwise Chancery would be ineffective, and that it would be absurd for Chancery to have power to hear and order cases, but not to execute judgment. ${ }^{29}$ BL MS Add 20700 ff. 158-158v.
} 
might also suggest that the claims about the prerogative were not altogether convincing.

However, by 1616 the links between Chancery, equity and the prerogative were clear. Francis Bacon advised James I to defend the Chancery (which Bacon described as "the court of your absolute power") in the Star Chamber "for the settling of your authority and strengthening of your prerogative according to the true rules of monarchy"..$^{30}$ The stress placed on the prerogative in 1616 may have been a tactic by supporters of the Chancery (or opponents of Edward Coke) to attract James I's personal attention to the jurisdictional dispute. This seems to have been the view of Timothy Tourneur (who clearly sided with the common law courts), who wrote that the Chancellor "made grievous complaint....to the King and the matter was much aggravated". James was informed or persuaded that the Chancery "was the very treasury of the ancient prerogative of the Crown and the mint of novel prerogative and that...the Lord Coke in this matter affronted principally the prerogative. And on this information, as was observed, the King was greatly incensed against the said Chief Justice."31 Tourneur thought that James had been persuaded that the Chancellor was "only the instrument of his prerogative" and that "his prerogative is

\footnotetext{
${ }^{30}$ J. Spedding (ed.), The Letters and the Life of Francis Bacon, 7 vols. (1869, Longmans, Green, Reader, and Dyer), vol. 5, p. 252

${ }^{31}$ BL MS Add 35957, ff. $54^{\mathrm{v}-55}$.
} 
transcendent to the common law". ${ }^{32}$ This would not be the first time that Ellesmere procured James's intervention on behalf of the Chancery in jurisdictional disputes, seemingly doing the same in the 1604 dispute between Chancery and the House of Commons over jurisdiction to judge the validity of election returns. ${ }^{33}$ However, in 1604, James seems to have regretted his involvement and accepted the view of the House of Commons that the dispute was "an usual controversy between courts about their pre-eminences and privileges". ${ }^{34}$ In 1616, James seems to have agreed with the arguments advanced that limiting the Chancery's jurisdiction was an attack on his own prerogative..$^{35}$

Tourneur's belief as to the cause of James's intervention in the 1616 dispute reveals the significance of the association between the prerogative and the Chancery. Even if this link had been made before the late-1570s, it became explicit in the years around 1580. Furthermore, from 1578 onwards, common lawyers unconnected with the Chancery discussed the relationship between equity and the prerogative. These

\footnotetext{
${ }^{32}$ BL MS Add 35957, f. $55^{\mathrm{v}}$.
}

${ }^{33}$ A. Thrush, 'Commons v. Chancery: the 1604 Buckinghamshire election dispute revisited' (2007) 26(3) Parliamentary History 301 and C. Russell, King James VI \& I and his English Parliaments (Oxford: Oxford University Press, 2011), pp. 28-30.

${ }^{34}$ J. R. Tanner, Constitutional Documents of the Reign of James I, 1603-25 (Cambridge: Cambridge University Press, 1930), pp. 224-5.

${ }^{35}$ See notes 116-129 below. 
discussions seem to have been based on genuine intellectual conviction, rather than any jurisdictional self-interest. By binding together the prerogative, equity and the Chancery, "an usual controversy between courts" instead touched upon matters of constitutional principle, as became apparent in 1616. This paper is concerned with the evidence showing when the association between the prerogative and equity emerged and suggests an explanation for this development in the influence of Jean Bodin.

\section{CHANCERY, EQUITY AND PREROGATIVE FROM 1578}

Three surviving texts suggest that the Chancellor's jurisdiction in equity was being explained by common lawyers as an aspect of the royal prerogative between 1578 and 1581. Unlike the remarks of Nicholas Bacon, none of these lawyers were directly associated with the Chancery. For these lawyers, the explanation of the Chancery as a prerogative court was not based simply on protection or expansion of the jurisdiction of the Chancery. Instead, the prerogative explanation for equity was derived from theory. Two of these lawyers, James Morice and William Lambarde, accepted the idea of the Chancery as exercising a prerogative power and for both of them we can identify influence from the work of Jean Bodin. The third lawyer, Robert Snagg, rejected the prerogative basis of the Chancery, but provides evidence that the idea was being discussed and may have been responding directly to Lambarde's work. This section ends by drawing attention to the emergence, in the 
1580s, of the idea of the Chancellor applying the king's conscience, a development which relates closely to the prerogative theory of equity considered here.

This development required a change not just in the theory of equity, but also in the nature of legal discussions of the prerogative. James Morice's reading on the prerogative in 1578 is a new style of discussion of the subject. Morice's reading was based not on the text of Praerogativa Regis, but the Statute of Westminster I, c.50, which referred to the statute not prejudicing the king or his crown. From this text, Morice considered what rights the Crown held as prerogatives. By doing so, Morice's discussion of the prerogative moved away from the old focus upon property law, instead focusing on the king's powers more generally. ${ }^{36}$ Morice's reading engaged with certain aspects of the "absolute" prerogative, such as the monarch's role in law-making, producing "what is probably the most complete analysis of the constitution by a common lawyer to have survived from the reign of Elizabeth" ${ }^{37}$ While there "is no indication that the views he expressed in 1578 were particularly controversial", Morice's reading demonstrates a major change in common law discussion of (and perhaps even thinking about) the prerogative, a change which regarded all royal powers as aspects of the prerogative. ${ }^{38} \mathrm{In}$

\footnotetext{
${ }^{36}$ For this change, see P. Halliday, Habeas Corpus, p. 66.

${ }^{37}$ C. W. Brooks, Law, Politics and Society in Early Modern England (Cambridge: Cambridge University press, 2008), p. 79 .

${ }^{38}$ Brooks, Law, Politics and Society, p. 81.
} 
undertaking his reading, Morice was breaking new ground. For present purposes, the significance of Morice's reading is that it provides evidence that in 1578 common lawyers were willing, and seemingly permitted, openly to discuss matters pertaining to the absolute prerogative. This new sphere of discussion meant that common lawyers could consider justifying, and elaborating upon, existing arrangements in terms of the royal prerogative. ${ }^{39}$

\section{A. William Lambarde La $^{40}$}

William Lambarde drew out the association between the Chancery and the monarch in his Archeion. Lambarde's views were the most fully developed and may have been influential. Not only did the Archeion circulate in manuscript before being printed in $1635^{41}$ but Lambarde became a Master in Chancery in 1592. Lambarde's influence on Egerton's work in the Chancery is often suggested, if difficult to prove. ${ }^{42}$ In relation to the Chancery and the prerogative, there is direct evidence of influence by

\footnotetext{
${ }^{39}$ For evidence that Morice also viewed equity as an aspect of the royal prerogative, see notes 73-74 below.

${ }^{40}$ On Lambarde, in addition to other works cited here, see generally R. M. Warnicke, William Lambarde, Elizabethan Antiquary 1536-1601 (London: Phillimore and Co., 1973).

${ }^{41}$ G. R. Elton, 'Arthur Hall, Lord Burghley and the Antiquity of Parliament', pp. 88-103 in H. LloydJones, V. Pearl and B. Worden (eds.), History and Imagination, essays in honour of H.R. Trevor-Roper (London: Duckworth, 1981), p. 101.

${ }^{42}$ See especially W. J. Jones, The Elizabethan Court of Chancery (Oxford: Clarendon Press, 1967), pp. 62 and $111-112$.
} 
Lambarde, ${ }^{43}$ as well as more inferential evidence of both influence and rejection of Lambarde's views. ${ }^{44}$

The Archeion purported to be a historical description of various English courts. In the case of the courts of equity (for Lambarde, the Chancery and the Star Chamber), this historical description was associated with normative justification for the existence of such courts. Both the historical and the normative content associates equity with the monarch. While the historical content can be traced to a letter written by Lambarde in 1577, Lambarde's normative ideas are first evidenced in 1579, in a discussion of the Chancellor, Chancery and equity which is almost identical to that in the Archeion. The normative explanation in this later exposition could be derived from the earlier material associating the Chancery with the prerogative, to which Lambarde had access. However, the Archeion contains no reference to this material. Instead, the link is made or justified through ideas from the work of Jean Bodin. ${ }^{45}$

\footnotetext{
${ }^{43}$ See notes 96-100 below.

${ }^{44}$ For possible influence on Anthony Benn, see notes 110-114 below. For rejection of Lambarde's view, see the discussion of Snagg, notes 85-88 below.

${ }^{45}$ Unless otherwise indicated, references to BL MS Lansd 621 following a reference to Archeion are to the 1579 draft. Alsop and Stevens were incorrect to claim that Lambarde was 'indifferent' to continental material and that it 'did little to serve his purpose' (J.D. Alsop and W.M. Stevens, 'William Lambarde and the Elizabethan Polity' (1986) 8 Studies in Medieval and Renaissance History 233, p. 251).
} 
Lambarde's historical discussion claimed that both law and equity had been administered before the Conquest by the King's court, which Lambarde identified with the King's Bench. ${ }^{46}$ In 1577, Lambarde explained that in the time when the king sat in the King's Bench personally, the "kinge and his greate Consalior [referring to the Chief Justice]...did after an absolute power mittigate the rigor of the lawe accordinge to Conscience even as the kinge did before the Conquest and as the lorde keeper nowe dothe." ${ }^{47}$ While Lambarde identified a power to provide equity in the monarch, "the lorde Chauncellors greatnes grewe by little and little although the tymes \& moments of those increases be not knowne unto me". ${ }^{48}$ There is no explanation in the letter of 1577 as to the need for this absolute power, or its source. The language of "absolute power" seems to be the same as that used by Stillington in 1469, simply a power not governed by rules.

By contrast, in 1579, Lambarde's discussion of the Chancery explained the need for equity and why the provision of equity was a uniquely royal and sovereign power. Lambarde described the need for someone to "supply the want, and correct the rigour of that Positive or written Law, which of it selfe neither is nor can be made such a perfect Rule, as that a Man may thereby truly square out Justice in all Cases

\footnotetext{
${ }^{46}$ Lambarde, Archeion, pp. 17-18; BL MS Lansd 621, f. $78^{\mathrm{v}}$ (1577 letter).

${ }^{47}$ BL MS Lansd 621, f. $79^{v}$.

${ }^{48}$ BL MS Lansd 621, f. 81v. Similarly f. $83^{\mathrm{v}}$.
} 
that may happen", a traditional explanation of the need for equity. Fulfilling this need was a duty undertaken by the monarch through his coronation oath and a consequence of the king's status as "the immediate minister of Justice under God". ${ }^{49}$ Not only did Lambarde regard this as a duty placed on the monarch, but this was a "soveraigne and preheminent Power". Both the coronation oath and the king's place under God would ensure that this power was uniquely associated with the monarch. ${ }^{50}$ In a passage which was written in 1589 , Lambarde discussed a parliamentary petition from 1402, in which it was requested "that none should be called before the Chancellor, or the Kings Councell, for any matter, but such onely as had no remedie at the Common Law". Lambarde observed that when such petitions had been made in other parliaments, "the Commons have seemed...to impugne this Kingly Prerogative" [emphasis added].51

From 1579, Lambarde referred to the Chancellor's authority as "extraordinary, and absolute even as the Kings owne", associating the Chancery with the king's

\footnotetext{
${ }^{49}$ Lambarde, Archeion, p. 42; BL MS Lansd 621, ff. $98^{\mathrm{v}-99}$.

${ }^{50}$ Lambarde, Archeion, p. 43; BL MS Lansd 621, f. 99.

${ }^{51}$ Lambarde, Archeion, p. 69. Although the petition, and Lambarde's commentary on it, considers the Chancery and equity, the passage occurs in Lambarde's discussion of 'criminal equity' in the Star Chamber. Folger MS V.a.207, dated 1589, is an autograph manuscript of Lambarde's material on the Star Chamber which came to form part of the Archeion.
} 
"preheminent Power". ${ }^{52}$ In a section of the Archeion written after 1593, Lambarde explained that the King committed to the Chancellor "his owne Regall, absolute, and extraordinarie preheminence of Iurisdiction in Civill Causes, as well for amendment as for supply of the Common Law." 53 For Lambarde, the Chancellor was "the Mouth, as it were, of the Prince". ${ }^{54}$ Consequently "his power is singular, and of it selfe, which may rule the person which is commandable by the absolute and Regall Justice of the Prince" ${ }^{55}$ This association between the monarch, the prerogative and equity was influenced by the work of Jean Bodin, in particular Bodin's République, printed

\footnotetext{
${ }^{52}$ Lambarde, Archeion, p. 41 n.26; BL MS Lansd 621, f. 98.

${ }^{53}$ Lambarde, Archeion, p. 39. See P. L. Ward, 'Appendix' in Lambarde, Archeion, p. 152 for discussion of the date of this section of the work.
}

${ }^{54}$ Lambarde, Archeion, p. 39. The idea of the Chancellor as the prince's voice is expressed in Thomas Smith's De Republica Anglorum (London, Henry Middleton, 1584), pp. 36-7. De Republica was written between 1562 and 1565 (I. W. Archer, 'Smith, Thomas' in H. C. G. Matthew and B. Harrison, The Oxford Dictionary of National Biography, 6o vols. (Oxford: Oxford University Press, 2004), vol. 51, p. 328). I can find no evidence that Lambarde had access to a manuscript copy of this work, although it did circulate. Ward has only found evidence of Lambarde using De Republica in his notes on the House of Commons, probably written in 1584 , suggesting that Lambarde used the printed text and explaining why this remark does not appear in Lambarde's 1579 text (P. L. Ward (ed.), William Lambarde's Notes on the Procedures and Privileges of the House of Commons (1584) (London: HMSO, 1977), pp. 5 and 7; for the attribution of these notes to Lambarde, see pp. 30-31). Lambarde seems to be the first person to use the idea of the Chancellor as the monarch's voice outside of the parliamentary context.

${ }^{55}$ Lambarde, Archeion, p. 40. 
in 1576. The difference between Lambarde's 1577 letter, and the 1579 text which became part of the Archeion, can be directly linked with Lambarde's reading of a very recent publication.

This is demonstrated in Lambarde's discussion of the necessity of both law and equity. ${ }^{56}$ Lambarde explains that "if either this Arithmeticall Governement, (as they call it) by rigour of Law onely, or this Geometricall Judgement at the pleasure of the Chancellour or Praetor onely should bee admitted; and yet if they bee well compounded together, a most sweete and harmonicall Justice will follow of them" ${ }^{57}$ In the République, Bodin referred to the provision of arithmetic and geometric justice, resulting in justice as a form of musical harmony. ${ }^{58}$ In doing so, Bodin mixed

${ }^{56}$ Other evidence of the influence of Bodin upon Lambarde can be found in the Eirenarcha, where Lambarde observes that the justice of the peace 'may exercise sometimes Legis actionem, and sometimes Iudicis officium, or (which is all one) Iudicium \& Decretum' (Lambarde, Eirenarcha, p. 63). The equivalence between the terms here is drawn from Bodin, Six Bookes, p. 333 (lib. III c. 5). The terms of legis action and iudicis officium are also present in the printed marginalia to the French printing in the passage where Bodin discusses harmonic justice (Bodin, Les Six Livres, p. 749).

${ }^{57}$ Lambarde, Archeion, p. 44; BL MS Lansd 621, f. $99^{\mathrm{v}}$.

${ }^{58}$ Bodin, Six Bookes, pp. 755-794 (lib. VI c. 6). The key passage is at p. 760. On Bodin's theory of harmonic justice, its wider intellectual background and significance, see A. Giuliani, 'Metaphors of justice. A mathematical-musical image in Jean Bodin (1576)', unpublished paper presented at the 2009 British Legal History Conference. I am grateful to Dr Giuliani for providing me with a copy of his paper. Bodin also used the harmonic ratio in his earlier Method for the Easy Comprehension of History 
Aristotelian ideas of justice as proportion with mathematical theory and Pythagorean ideas of music as mathematical to produce the idea of justice itself as a form of musical harmony. References to arithmetic and geometric justice are not uncommon in the early-modern period, ${ }^{59}$ but as Bodin himself made clear, with typical early-modern honesty, associating these ideas with musical harmony was a new step. ${ }^{60}$ Unless Lambarde independently reached the same theoretical position as Bodin, in the three years after the République was printed, Lambarde's theoretical discussion of equity and the Chancery was informed by a reading of the French theorist. ${ }^{61}$ The same idea of justice as musical harmony can also be seen in later

(New York: Columbia University Press, 1945), pp. 286-8. This was printed in 1566, and Lambarde acquired a copy in 1571 (see Ward, William Lambarde's Notes, p. 39 n. 14). However, the Method says nothing about equity or judging, so cannot be the source for Lambarde's discussion.

${ }^{59}$ In addition to the references to continental (especially French) material in Giuliani, 'Metaphors of Justice', see J. Hales, An Oration in Commendation of the Lawes cheiflye of the lawes of this moste noble Realme of Englande (BL MS Harl 4990, f. 1 at ff. 42-44), for an English example from the 1540s.

${ }^{60}$ Bodin, Method for the Easy Comprehension of History, p. 286 and Bodin, Six Bookes, pp. 755-6 (lib. VI c. 6).

${ }^{61}$ Lambarde seems to have been attracted to the metaphor of justice and music, even using it in a speech to a jury in his role as a Justice of the Peace in Kent (C. Read (ed.), William Lambarde and Local Government, His "Ephemeris" and Twenty-nine Charges to Juries and Commissions (Ithaca NY, Cornell University Press, 1962) p. 124). 
writers on the Chancery, suggesting continued influence from Bodin (or perhaps Lambarde) ${ }^{62}$

A further suggestion that Lambarde's view of the Chancellor's powers may have been shaped by Bodin is visible in Lambarde's analogy between the Chancellor and the Roman praetor. This analogy seems to have been current in Elizabethan England, but was not disseminated in print until after Lambarde had formed his views. ${ }^{63}$ Lambarde's comparison may have been formed by Bodin's use of the praetor as a prime example of equitable intervention in the application of the law.

A complication in applying Bodin's ideas to England lay in Bodin's background in the ius commune, where equity was associated with interpretation of textual law. ${ }^{64}$ Much of Bodin's discussion of equity is based on this interpretative power. ${ }^{65}$ In England, by contrast, much of the work of the Chancellor was concerned with the

62 See notes 110-114, 124-125 and 132 below. Alsop and Stevens suggest that the idea of law and equity leading to 'harmonicall Justice' may have been the 'coherent and orthodox moderate view' in Elizabethan England (Alsop and Stevens, 'William Lambarde', p. 247). If that is correct, this orthodox and moderate view came from Bodin.

63 The first reference I have found is in Smith, De Republica Anglorum, p. 54. For the evidence that Lambarde only had access to the printed version of this text (1584), see note 54 above.

${ }^{64}$ As Barton observes of epieikeia, '[p]rimarily, it was a canon of interpretation' (Barton, 'Introduction', p. xliv).

65 See, especially Six Bookes, pp. 763-764 (lib. VI c. 6). 
unwritten common law. This difficulty in directly applying Bodin may have been noted by Lambarde, who solved the problem by incrementally changing the nature of the law in relation to equity, so that equity could operate in the context of the unwritten common law. First, Lambarde referred to the need for equity in the context of "written Lawes". ${ }^{66}$ Equity was then discussed in relation to "Positive or Written law" and finally to "the Positive and Common Law" ${ }^{67}$

In the République, the mark of sovereignty was the power to make or unmake laws. ${ }^{68}$ Consequently, certain aspects of equity were limited to a sovereign. In relation to equity, "the magistrat how great soever he be, cannot of himselfe derogat from the law, and much lesse abrogat the same: for these things we have shewed properly to belong unto soveraigntie". ${ }^{69}$ By contrast, "equitie referred unto a soveraigne prince, is as much as for him to declare or expound, or correct the law", but equity referred

\footnotetext{
66 Lambarde, Archeion, p. 43; BL MS Lansd 621, f. 99.

${ }^{67}$ Lambarde, Archeion, p. 44; BL MS Lansd 621, f. $99^{\mathrm{v}}$.

${ }^{68}$ Q. Skinner, The Foundations of Modern Political Thought, 2 vols. (Cambridge: Cambridge University Press, 1978), vol. 2, p. 289; M.P. Gilmore, Argument from Roman Law in Political Thought 1200-1600 (Cambridge MA: Harvard University Press, 1941), p. 104.

${ }^{69}$ Bodin, Six Bookes, p. 335 (lib. III c. 5). The difference in the equity provided by the prince and by lesser magistrates in Bodin's thought has been noted by J. E. Shaw, 'Writing to the Prince: supplications, equity and absolutism in sixteenth century Tuscany' (2012) 215 Past and Present 51, p.
} 54. 
to a magistrate could only permit the magistrate to "asswage and mitigat the rigor of the law". ${ }^{70}$

In Lambarde's work, the Chancellor mixed both the equitable powers in lesser magistrates and the equitable powers of the sovereign. According to Lambarde, the Chancellor could "cancell and shut up the rigour of the generall Law", like magistrates in Bodin. ${ }^{71}$ However, the king had also delegated to the Chancellor "his owne Regall, absolute and extraordinarie preheminence of Jurisdiction in Civill Cause, as well for amendment as for supply of the Common Law" [emphasis added]. ${ }^{72}$ This power to amend the law was an element of sovereignty according to Bodin, albeit a form of sovereignty which as correction of the law was also described by Bodin as a form of equity. For Lambarde, such a correction of the law was a uniquely royal power, albeit delegated to the Chancellor.

Lambarde's association between the authority of the Chancellor and Chancery with the monarch was therefore a consequence of his reading of Bodin's République between 1577 and his second discussion of the Chancery in 1579. Lambarde presented equity as a uniquely royal function and an inherent element of being

\footnotetext{
${ }^{70}$ Bodin, Six Bookes, p. 763 (lib. VI c. 6).

${ }^{71}$ Lambarde, Archeion, pp. 31-2; BL MS Lansd 621, f. 96.

${ }^{72}$ Lambarde, Archeion, p. 39. This remark was added after 1593.
} 
sovereign, giving Chancery a privileged position in the legal system as a court which exercised the monarch's prerogative power of equity on his behalf.

\section{B. James Morice}

Although Morice never discusses equity in the surviving texts of his reading on the prerogative, he did state that he intended to discuss the Chancellor's role in the (undelivered) thirteenth division of the reading. ${ }^{73}$ That division was given the heading "What Prerogatives and Rights the king hath in and concerning the suites and accions of one Subiect against another". ${ }^{74}$ Morice therefore seems to have associated the Chancery, equity and the prerogative. On the basis of the surviving texts we cannot investigate the development of Morice's views any further, although there are tantalising hints that in other parts of his reading Morice was influenced by Bodin. Given that William Lambarde clearly used Bodin to associate equity with the prerogative, the same links may have been formed by Morice.

Evidence of influence from Bodin is found in Morice's discussion of the law-making prerogative. In his République, Bodin stressed that the mark of sovereignty was the power to make or unmake laws. ${ }^{75}$ In Morice's reading, the first division is entitled "What Righte of Prerogative and preheminencye the king hath in and concerning the

\footnotetext{
${ }^{73}$ BL MS Egerton 3376, f. $27^{v}$.

${ }^{74}$ BL MS Egerton 3376, f. 9.

${ }^{75}$ See note 68 above.
} 
making and establishing of lawes". ${ }^{76}$ This is the only heading which refers to the king's prerogative and pre-eminence, rather than just his prerogative. ${ }^{77}$ The stress on pre-eminence and the placing of this division as the first in the reading suggest that law making was the most important of the monarch's powers, applying Bodin's idea of law-making as the key indication of sovereignty.

Furthermore, Morice's discussion of the law-making prerogative is reminiscent of Bodin in places. ${ }^{78}$ In particular, he states that "the begyning of the Parliament the

${ }^{76}$ BL MS Egerton 3376, f. 8. The same heading appears in the version of the reading which Baker identifies as possibly Morice's autograph (J. H. Baker, Readers and Readings in the Inns of Court and Chancery (13 Seld. Soc. Supplementary, 2000), p. 370, referring to BL MS Add 36081, f. 237), although Brooks is more sceptical (Brooks, Law, Politics, and Society, p. 79 n. 132).

77 The language of preeminence is used by Morice as a definition of the prerogative (BL MS Egerton 3376 , f. 8), but nowhere else in the text are the two words both used for a single prerogative. Preeminence as an element of the definition of the prerogative was already to be found in the opening of Staunford's writing on the prerogative (An Exposicion of the Kinges Prerogative (London: Richard Tottel, 1567), f. 5), but not in the readings on Praerogativa Regis contained in McGlynn's study (M. McGlynn, The Royal Prerogative and the Learning of the Inns of Court (Cambridge: Cambridge University Press, 2003)). The prerogative was associated with the language of pre-eminence by at least 1534, when the two are listed together in the Act of Succession (Stat.25.Hen.8.cap.22) and in an oath sworn by new bishops (J. M. Gray, Oaths and the English Reformation (Cambridge: Cambridge University Press, 2013), p. 65).

${ }^{78}$ It is in relation to law-making and sovereignty that Brooks also detects influence from Bodin on Morice (Brooks, Law, Politics and Society, p. 8o). 
continuance and the end thereof is by thonlie aucthoritie of the Prince", ${ }^{79}$ just as Bodin explains that the "estates of England are never otherwise assembled...than by parliament writs, and expresse commandements proceeding from the king. Which showeth verie well that the estates have no power of themselves to determine, command, or decree anything; seeing that they cannot so much as assemble themselves; neither being assembled, depart, without expresse commaundement from the king" ${ }^{80}$ Such similarity is hardly determinative, but Morice's consideration of whether or not the king is bound by law echoes Bodin in significant ways. Morice reached the conclusion that "rightly understood", the king is not bound by law, a conclusion which seems to be the same as that of Bodin. ${ }^{81}$ However, this did not mean that the king could govern "at his will and pleasure". Morice referred to the coronation oath of the king, and asked "What can be more meete or seeming to equite then the Prince to be bound by his owne law"? ${ }^{82}$ Bodin also referred to the oath of kings to govern according to law and like Morice linked this to equity,

\footnotetext{
${ }^{79}$ BL MS Egerton 3376, f. 11.
}

${ }^{80}$ Bodin, Six Bookes, p. 96 (lib. I c. 8). Bodin identifies his source as the English civilian and ambassador, Valentine Dale.

${ }^{81}$ BL MS Egerton 3376, f. $13^{\mathrm{v}}$. The question of how far Bodin's sovereign was constrained is a controversial one, but Bodin does seem to have recognised some limits on the monarch's powers. See, Skinner, Foundations of Modern Political Thought, vol. 2, p. 293 for discussion and further references. Morice's detailed conclusion is not identical to that of Bodin, but the important point is the compatibility of the general view and approach to the discussion of the monarch.

${ }^{82}$ BL MS Egerton 3376, f. $13^{\mathrm{v}}$. 
explaining that "the equitie of the law which he hath sworne to keepe, ceasing, he is no more bound to the keeping thereof, by his oath". ${ }^{83}$ There are clearly strong parallels here between Morice's discussion of the law-making power and Bodin's discussion of sovereignty.

\section{Robert Snagg}

Snagg's Antiquity E Original of the Court of Chancery, printed in 1654, was probably originally delivered as a reading in the Middle Temple in $1581 .{ }^{84}$ In it, Snagg raises the question of whether proceedings in Chancery complied with the per legem terrae requirements of Magna Carta. Were proceedings in the Chancery authorised by the law of England? Snagg's conclusion was that the authority of the Chancery and the Lord Chancellor derived from the law of England.

However, when referring to the Chancellor and the Chancery, Snagg observed that: looking into the course of the proceedings in the Chancery, by the Lord Chancellor of England, from time to time, it seemed as though that Office had

\footnotetext{
${ }^{83}$ Bodin, Six Bookes, p. 93 (lib. I c. 8). The original French is 'la justice de la loy' (Bodin, Les Six Livres, p. 98), but the 1606 translation by Knolles' quoted here demonstrates that an early-modern Englishman might translate the French 'justice' as 'equity'. See note $\mathbf{1 1 8}$ below for the Latin iustitia also being translated other than in the obvious literal sense.

${ }^{84}$ See Baker, Readers and Readings, pp. 610-611. For the controversy about the readership in the Middle Temple in February 1581, see, ibid., p. 354.
} 
been besides the Law, erected out of the absolute authority that the Conquerors claimed; and that it hath been continued from time to time against the Law, and the Provision of that Charter and Parliament, as it were by a Prerogative above the Law 85 (emphasis added)

While Snagg rejected his initial view, the link with the prerogative is clear.

There is some evidence that the remarks in Snagg's reading may have been a response to views on the Chancery. Snagg discussed the meaning of the word "Chancellor", acknowledging "wherein all agree, that he is called Cancellarius, à Cancellando. But what he may Cancell, whereby he had that honour, hath been doubted. Some have said, that he had authority Cancellare iniquam Legem Communem, $\mathcal{E}$ judicare secundum Conscientiam." 86 In the Archeion, Lambarde explained that the Chancellor "in his Court of Equitie, he doth (when the Case requireth) so cancell and shut up the rigour of the generall Law", a view which Snagg clearly rejected. ${ }^{87}$ Lambarde's view was only expressed in 1579 and then the Archeion. In his 1577 letter on the Chancery, Lambarde referred to the Chancellor's name as referring to the cancellation of records (a point he reiterated in the Archeion) and that he "conteyneth the lawe within certen barres or boundes and mittigateth the suertie and Rigor

\footnotetext{
${ }^{85}$ R. Snagg, The Antiquity and Original of the Court of Chancery, and authority of the Lord Chancellor of England (London: Henry Seile, 1654), p. 31.

${ }^{86}$ Snagg, Antiquity, pp. 43-44.

${ }^{87}$ Lambarde, Archeion, pp. 31-2; BL MS Lansd 621, f. 96.
} 
thereof accordinge to aequum bonum to equitie \& good conscience". ${ }^{88}$ There is no reference to cancelling the law here, although it might be implied.

\section{The Idea of Chancery applying the King's Conscience}

The idea of the Chancellor as the keeper of the "king's conscience" is now largely treated as a commonplace. ${ }^{89}$ But a focus on the monarch's conscience stands in marked conflict to the typical early-modern theory of conscience as in some way an objective standard..$^{90}$ Furthermore, so far as can be seen, the first identified reference to the Chancellor as the monarch's conscience was by Christopher Hatton, Lord Keeper between 1587 and $1591 .{ }^{91}$ After Hatton, such language becomes more common. ${ }^{92}$ As Chancellor, Lord Ellesmere referred to himself as applying the king's

${ }^{88}$ BL MS Lansd 621, f. 81.

${ }^{89}$ See, e.g., G. W. Thomas 'James I, Equity and Lord Keeper John Williams' (1976) EHR 506, p. 514 ('[t]he chancellor, of course, was the keeper of the king's conscience').

${ }^{90}$ See generally D. R. Klinck, Conscience, Equity and the Court of Chancery in Early Modern England (Farnham: Ashgate, 2010).

${ }^{91}$ G. Spence, The Equitable Jurisdiction of the Court of Chancery, 2 vols. (Philadelphia: Lea and Blanchard, 1846), vol. 1, p. $4^{14}$ ('the holy conscience of the Queen, for matter of equity, that is in some sort committed to the Chancellor').

${ }_{92}$ Although never the only description of the nature of the conscience which was applied. Objective ideas remained, as did claims that the Chancellor was following his own conscience (see, e.g., Klinck, Conscience, Equity, p. 162). 
conscience in some cases. ${ }^{93}$ By 1616 , James I could say that the Chancery "is called the dispenser of the King's Conscience", seemingly treating the description as a commonplace. ${ }^{94}$ In 1621 Francis Moore wrote to Bishop Williams to remind him that as Chancellor he was to judge according to conscience, "but that Conscience is the King's committed to the Chancellor", stressing that the Chancellor was to ignore his private conscience and to judge "according to the King's Conscience". ${ }^{95}$ This change in the notion of conscience which was to be applied in the Chancery stressed a link with the king.

\section{JURISDICTION AND PREROGATIVE IN CHANCERY CASES, 1595-1615}

In two cases in 1595 , references to the Chancery as a court deriving directly from the royal prerogative and the monarch can be found. This association with the prerogative was used to undermine other, inferior, courts which claimed an equitable jurisdiction. In Cheyney v. Godfrey the Cinque Ports claimed an equitable jurisdiction to the exclusion of the Chancery, a jurisdiction not based upon any express grant. Two masters decided that "this high court...has the dispensation of

\footnotetext{
${ }^{3}$ Anon (1612, Chancery) in Bryson, Cases Concerning Equity, vol. 2, p. 398; Martin v Marhsall (1615, Common Pleas) in ibid., p. 444.

${ }^{94}$ James I, A Speach in the Starre-Chamber, the XX of June. Anno 1616 in J. P. Sommerville (ed.), King James VI and I: Political Writings (Cambridge: Cambridge University Press, 1994), p. 214.

${ }^{95}$ D. Yale (ed.), Lord Nottingham's 'Manual of Chancery Practice' and 'Prolegomena of Chancery and Equity' (Cambridge: Cambridge University Press, 1965), p. 78.
} 
her Majesty's own pre-eminent and absolute judgment, from which no subject is or can be excused" and that only express words could found any exclusion of the Chancery jurisdiction. ${ }^{96}$ The judgment of the Chancery was that of the monarch. The case was decided by two of the Masters in Chancery, one of whom is identified as William Lambarde. Lambarde's prerogative model of the Chancery, which he developed in the late-1570s under the influence of Jean Bodin, came to be directly applied by Lambarde himself when he became a significant figure in the Chancery. ${ }^{97}$

Bodin's influence may also explain the outcome of this particular case. For Bodin, in his discussion of equity, the power to give judgment other than by the law could only be given "by vertue of his [a judge's] office" or from "the princes rescript or commission" ${ }^{98}$ In England it was clear that the judges did not have a power to judge by equity by virtue of their office (other than in matters of statutory interpretation). Such a power was therefore necessarily derived directly from the prince. This would explain Lambarde's decision in Cheyney v. Godfrey - without an express grant from the prince, no magistrate had authority to judge by equity.

\footnotetext{
${ }^{96}$ Cheyney v. Godfrey (1595) in C. Monro (ed.), Acta Cancellariae (London: William Benning \& Co., 1847), pp. 25-26.

${ }^{97}$ For other cases in the Chancery involving Lambarde as master, see Warnicke, William Lambarde, pp. 96-98.

${ }_{98}$ Bodin, Six Bookes, p. 767 (lib. VI c. 6). Similarly p. 763.
} 
However, it is not just in cases in which Lambarde's involvement can be proved that the association between the Chancery and the monarch can be seen. In the second case in 1595, Dawborne v. Garbrand, the Chancery went further. The University of Oxford claimed an equitable jurisdiction. Here, even the effectiveness of an express grant of equitable jurisdiction was doubted, on the basis that the Queen might not be able to delegate an inherent element of her prerogative: "[ $t$ ]his court is not well satisfied that any such privilege as the said university claimeth for the cognizance and deciding of matters of equity can be by law granted by charter out of the person and prerogative of the prince, but that the cognizance and deciding thereof appertaineth to this honourable court" [emphasis added]. ${ }^{99}$ The Chancery here linked equity both with the person of the monarch, as in the claims to be the monarch's conscience, and with the prerogative itself. By basing the court's authority on an inherent aspect of the monarch's own power and authority, the Chancery was able to assert its jurisdictional exclusivity. ${ }^{100}$

99 Dawborne v. Garbrand (1595) in Monro, Acta Cancellariae, pp. 680-1. Coke was similarly adverse to the creation of new equity jurisdictions, but not because of the prerogative basis of equity courts. For Coke, the king could not create an equity court by letters patent because an equity judge would be 'without controulment' (The Case of the Lords President of Wales and York 12 Co. Rep. 51, f. 52).

100 This is similar to Edward Coke's use of the prerogative to justify the King's Bench's jurisdiction in habeas corpus. See Halliday, Habeas Corpus, pp. 12-13. Francis Bacon also described equity as an element of the royal prerogative, but used this to justify the king's power to establish equity courts other than the Chancery (in this case, the provincial councils). Bacon referred to this prerogative as the king's 'sovereign power', a power which included the 'power to stay suits at the common law; yea 
In the second decade of the seventeenth century, similar arguments can be seen. In 1612, it was held that the Chancery always retained jurisdiction to hear equity cases, even if they should have been heard in other equity courts, such as the court of the Duchy of Lancaster. This was explained as the king retaining a "supreme power" to provide equity. ${ }^{101}$ In Michaelmas term 1615, when arguing that the city of York could not establish a court of equity by prescription, it was explained that counties palatine "have jura regalia and, by consequence, a court of chancery". ${ }^{102}$ In both of these cases, any chancery jurisdiction was fundamentally tied to the king's special royal power to provide equity, indeed was a consequence of this uniquely royal power.

\section{Bodin, PRerogative AND the CHANCERY IN 1615/16}

When defending the Chancery during the controversy of $1615 / 16$, participants in the debates typically took one of two positions. The first was a narrow defence focused on the particular arguments made, and statutes relied upon, by the supporters of the

\footnotetext{
pro bono publico to temper, change, and control the same' (Bacon, 'A View of the Differences in Question betwixt the King's Bench and the Council in the Marches' (1607), in Spedding, The Letters and the Life, vol. 3, pp. 371 and 373).

101 Anon (1612, Chancery) in Bryson, Cases Concerning Equity, vol. 2, p. 398.

${ }^{102}$ Martin v. Marhsall (1615, Common Pleas) in Bryson, Cases Concerning Equity vol.2, p. 444 at 445.
} 
common law courts. ${ }^{103}$ The second approach was to stress the status of the Chancery as a prerogative court, challenges to which were challenges to the prerogative itself. If the notion of the prerogative lying behind the provision of equity was associated with ideas of sovereignty from Bodin, this would explain why the Chancery necessarily needed to prevail over the common law courts: if the common law courts were able to prevent the application of equity, the king would have lost an element of sovereignty.

Three texts from the 1616 controversy about the Chancery reveal continuing influence from Bodin. ${ }^{104}$ Two of these texts stress the association between the Chancery, equity and the prerogative. The third sought to undermine the Chancery, and to do so engaged with material from Bodin. ${ }^{105}$ None of the texts draw out the

${ }^{103}$ Ellesmere's 'A Breviate or Direccion for the Kinges Learned Councell collected by the Lord Chauncellor Ellesmere' (in Knafla, Law and Politics, pp. 319-336) is an excellent example. See also William Hakewill's discussion, BL MS Lansd 174, ff. 226-235".

${ }^{104}$ Given that by 1580, Gabriel Harvey thought it very likely that on entering a scholar's study one would find him reading either Bodin's République or Le Roy's De l'excellence du gouvernement royal (1575), the appearance of Bodin in the early seventeenth century is not especially surprising (E. J. L. Scott (ed.), Letter-Book of Gabriel Harvey. AD 1573-1580, Camden Society New Series vol. 33 (London: Camden Society, 1884), p. 79).

${ }^{105}$ Not all participants in the debate, even on the side of the Chancery, used the same ideas from Bodin as Lambarde. Most notably, Lord Chancellor Ellesmere did not focus on the prerogative (contrary to the assertions of Timothy Tourneur), nor the idea of justice as musical harmony. 
association between ideas of sovereignty, English equity and the Chancellor as clearly as Lambarde. Arising in a different context and for different purposes, the arguments are less clear, but there is evidence that Bodin remained an influence on thinking about the unique authority of the Chancery. The texts continue to make reference to the role of equity in providing justice as musical harmony, suggesting a continuing influence from Bodin. ${ }^{106}$

\section{A. Anthony Benn}

Benn was a lawyer whose surviving writings are generally supportive of royal authority against the common law courts. Benn wrote a tract in support of the Chancery in which he stressed the association between the Chancery and the

Ellesmere's contributions seem to have been resolutely technical, focusing on the meaning of the

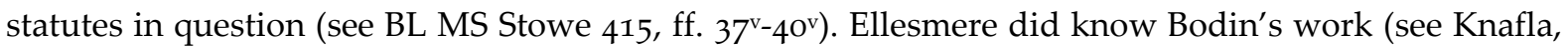
Law and Politics, pp. 75 and 319), but chose not to use the discussion of equity found there and seems generally to have rejected the practical application of theory about the prerogative (Russell, King James VI and I, p. 152). This may explain why the prerogative was not a concern in Finch v. Throgmorton (see note 9 above) - the parties to the debate were not those interested in seeing equity in the Chancery as an issue of political theory.

${ }^{106}$ Not all such prerogative arguments made use of Bodin's ideas (or at least, do not do so in a manner which can be identified). Most obviously, Francis Bacon's letter to James clearly associated the Chancery with the prerogative, but does not explain this link (see above, note 30). 
prerogative. ${ }^{107}$ Benn refers to the Chancery, the Exchequer and letters under the Privy Seal from the King's Council as "Courts of Prerogative". 108

Benn's discussion includes the musical metaphor from Bodin of the relationship between law and equity, albeit in different terms to that seen in Bodin and Lambarde. While for Bodin and Lambarde the Aristotelian underpinnings of the theory are apparent, Benn changes the metaphor. For Benn, "Justice is her [equity's] plaine song, as it is the plaine song of the lawe, the descant is manyfold, yet no other then such as the law also makes her musick of; It is with equity as with law" ${ }^{109}$

Brooks has observed that Benn's writings reveal links with Bodin's thought, and so the appearance of the musical metaphor, and the association of equity with the prerogative, may not be surprising. ${ }^{110}$ However, it may be that in this particular instance, Benn was being influenced not by Bodin directly, but by Lambarde. In addition to using the idea of music in association with justice, Benn refers to a

\footnotetext{
107 BL MS Lansd 174, ff. 205-215.

108 BL MS Lansd 174, f. $211^{\mathrm{v}}$.

109 BL MS Lansd 174, ff. 211 ${ }^{\mathrm{v}}$-212. At this point is his discussion, Benn rejects the argument of uncertainty in equity, arguing that equity is no more uncertain than law, hence the description of equity as 'like' the law. Baker dismisses this passage as 'florid' language, but in fact it reveals the influences on Benn (Baker, 'The Common Lawyers and the Chancery', p. 382).

${ }^{110}$ Brooks, Law, Politics and Society, p. 141.
} 
parliamentary petition from the reign of Henry IV which complained about the use of subpoenas from the Chancery and the king's response. ${ }^{111}$ The same petition and response is found in Lambarde's Archeion, near the end of a section showing the complaints made against the Chancery and other royal interventions in the legal system, with some of the royal responses to them. ${ }^{112}$ It is in this section that Lambarde refers to the role of the Chancery as "prerogative", ${ }^{113}$ and it is in this context that Benn also refers to the Chancery as a prerogative court. ${ }^{114}$

\section{B. James I}

Timothy Tourneur seems to have regarded the king as someone manipulated into his intervention in the dispute over the Chancery's jurisdiction. ${ }^{115}$ Even if James was originally provoked into action, the result was his Speach in the Star Chamber in 1616, a speech in which James revealed some of his own views on the relationship between law, equity and prerogative in the English context. It seems likely that James agreed with Francis Bacon's recommendation to use the Star Chamber to resolve the Chancery dispute; the Speach was another opportunity for James to demonstrate to the wider world his understanding of the "true rules of

\footnotetext{
${ }^{111}$ BL MS Lansd 174, ff. 211-211 ${ }^{\mathrm{v}}$.

${ }_{112}$ Archeion, pp. 68-73 at 71-72.

${ }^{113}$ See note 51 above.

114 See note 109 above.

${ }^{115}$ See notes 31-32 above.
} 
monarchy". ${ }^{116}$ The Speach enabled James to show that he could not only write The Trew Law of Free Monarchies, but that he could apply this true law as a king.

In the Speach, James revealed a strong association between the Chancery and the royal prerogative. James described the Chancery as "mixing Mercy with Justice", and then stated that "the Kings Throne [is] established by Mercy and Justice". ${ }^{117}$ This idea seems to be a combination of Proverbs 20.28 (where the throne is established by mercy) and the Latin vulgate of Proverbs 25.5 (in which the throne is established by justitia, although early-modern English translations use "righteousness"). ${ }^{118}$ For James, the Chancery therefore performed an essential biblical function on his behalf, securing the throne in a way which the common law courts, which "proceed onely according to the strict rules of Law", did not and could not. ${ }^{119}$ This special role for the Chancery led James to explain that "as I am bound in my Conscience to

\footnotetext{
116 See note 30 above.

117 James I, Speach, p. 214.

118 Benn explicitly referred to Proverbs 20.28 in his discussion of the Chancery ('mercy and trueth preserve the King and his throne shalbe established by equity'), BL MS Lansd 174 f. 206. The marginal note is to Proverbs 20. Bacon also referred to Proverbs 20.28 to demonstrate that 'by the ordinance of God' the power to establish courts of equity belonged inherently to the king (Bacon, 'A View of the Differences', pp. 372-3).

119 James I, Speach, p. 214.
} 
maintaine every Courts Jurisdiction, so especially this" [emphasis added], further privileging the Chancery.

While James did not explicitly refer to the Chancery as prerogative court, the discussion of the Chancery was part of a disquisition as to the limits to which judges of the common law courts were subject. "First, Incroach not upon the Prerogative of the Crowne". ${ }^{120}$ The second limit was "not to invade other Jurisdictions". ${ }^{121}$ Although these two topics appear unrelated, after stating the jurisdictions of the King's Bench, Common Pleas and Exchequer, James then instructed the judges that while they were "to give me no more right in my private Prerogative, then you give to any Subject...as for the absolute Prerogative of the Crowne, that is no Subiect for the tongue of a Lawyer, nor is lawfull to be disputed". ${ }^{122}$ James then discussed the jurisdiction of the Chancery. The structure of the Speach therefore suggests that James did associate the Chancery with the absolute prerogative, an impression strengthened by James's claim that the Chancellor should not "exceed his limite" but that if he were to do so "the King onely is to correct it", suggesting that the Chancery was part of the "absolute Prerogative of the Crown" which was not to be disputed,

\footnotetext{
${ }^{120}$ Ibid., p. 212.

121 Ibid., p. 213.

122 Ibid., p. 214.
} 
especially as James described any such jurisdictional litigation as "in contempt of our Authoritie". ${ }^{23}$

The Speach shows considerable influence from Bodin. Most obviously, James used a musical metaphor in relation to the Chancery and other courts, but without any evidence of the underlying Aristotelian theory. James proclaimed that "[i]t is a speciall point of my Office to procure and command, that amongst Courts there bee a concordance, and musical accord" [emphasis added], ${ }^{124}$ later encouraging the judges to "labour to keepe that sweete harmonie, which is amongst those sisters the Muses." [emphasis added $]^{125}$

Furthermore, Bodin recommended that sovereigns should not themselves act as judges, largely for pragmatic reasons. ${ }^{126}$ In his Speach, James explained that to intervene in a case which directly concerned him or was a "great cause" might cause people to suspect partiality either towards James himself or one of the parties, and that to intervene in a "meane cause was not worthy of me". ${ }^{127}$ Impliedly, James could intervene in this dispute as a "great cause" not concerning any particular parties.

\footnotetext{
${ }^{123}$ Ibid., p. 215.

124 Ibid., p. 215.

${ }^{125}$ Ibid., p. 217.

${ }^{126}$ Bodin, Six Bookes, pp. 506-517 (lib. IV c. 6).

${ }^{127}$ James I, Speach, p. 207.
} 
Rather, the dispute between the common law courts and Chancery concerned "a speciall point of my Office". ${ }^{128}$ In the République, Bodin stated that because equitable intervention "greatly concerned the rights of soveraigntie, princes...reserved unto themselves the expounding and correcting of the laws, especially in cases doubtful, betwixt the Law and Equitie", ${ }^{129}$ just as James was doing in the Speach. James therefore seems to have used an idea from Bodin both to justify his intervention to his domestic audience and to explain his departure from Bodin's own advice.

\section{Francis Ashley}

In his 1616 reading on Magna Carta and the meaning of lex terrae, Ashley, like Snagg, concluded that equity was part of the lex terrae, not an alternative or competitor to it. ${ }^{130}$ The reading was delivered in Michaelmas 1616, after Coke had been dismissed from his post. The prefatory speech to the reading strongly hints at Ashley's support for Coke. Not only did Ashley cite the preface to Coke's Eighth Reports on the importance of Magna Carta, he explicitly relied on Magna Carta to declare that the king cannot delay justice by orders under the great or privy seal, impliedly

\footnotetext{
128 Ibid., p. 215.

${ }^{129}$ Bodin, Six Bookes, p. 764 (lib. VI c. 6). Bodin's view was probably informed by C.1.14.1.

${ }^{130}$ On Ashley's reading, see Halliday, Habeas Corpus, pp. 145-147.
} 
supporting Coke's conclusion on this point concerning the writ non procedendo rege inconsulto and perhaps in the Case of Commendams. ${ }^{131}$

Interestingly, Ashley also makes use of the musical metaphor about law and justice. However, unlike writers in support of the Chancery, Ashley uses the metaphor in relation to Magna Carta and other laws in England. According to Ashley, "The old statutes which were the auntient Common Lawes are the body and the Text, and all Records and Reports are but Commentaryes and exposicions upon them, and so is this law in effect the ground, and the rest subsequent but florishes upon it, this the base and others the descant" [emphasis added]. ${ }^{132}$ Ashley subverts the musical idea of

${ }^{131}$ BL MS Harl 4841, f. 3. Halliday notes that '[t]he timing [of Ashley's reading] may have mattered', but does not directly consider the content of the reading in this regard (Halliday, Habeas Corpus, p. 394 n. 27). On the controversy concerning the writ non procedendo rege inconsulto see Hart, The Rule of Law, pp. 104-5. The Case of Commendams did not involve a sealed order from the king, merely a letter, and so was not directly covered by Ashley's point. However, for an early-modern common lawyer to accept that justice could not be delayed by a formal writ but could be delayed by letter seems unlikely, suggesting Ashley was alluding to the Case of Commendams. For the letters and debates, see Acts of the Privy Council of England 1615-1616 (London: HMSO, 1925), pp. 595-609.

${ }^{132}$ BL MS Harl 4841, f. 3 . The reference to the old statutes as the text of the common law and reports as commentaries is taken from the preface to Coke's eighth reports (E. Coke, La Huictme Part des Reports de Sir Edw. Coke (London: Societie of Stationers, 1611), sig. Aii). Lambarde referred to the three estates in parliament as being 'harmonicall', 'because from such, and so well-tuned a Base, Meane, and Treble, there proceedeth a most exquisite consent, and delicious melodie' (Lambarde, Archeion, p. 
justice found in Bodin to suit his own ends. For Ashley, equity was a part of lex terrae, but at best one part of the "descant" of the harmony of justice. That harmony depended upon Magna Carta. Equity, which was clearly associated with the prerogative in the 1616 debates, could not work against Magna Carta if justice were to flourish. The controversial implication about the relationship between the prerogative and Magna Carta is clear, but not made explicit.

\section{CONCLUSION}

By the 1650s, the Chancery's association with the prerogative, and the use of Bodinian terms, seems to have been widely accepted. Henry Robinson's proposal to abolish the Chancery condemned the court as "such an absolute Prerogative Royall, as that every knave, oppressor, or revengefull person is able...to commence and continue a suite". ${ }^{133}$ An anonymous pamphlet in support of the Chancery could, by contrast, praise the court as the "conscience of the Supreme Authority", language which echoes Bodin's concept of the sovereign, while avoiding awkward questions

\footnotetext{
126), which may suggest Ashley's use of the musical terms originated in Lambarde. Lambarde's discussion here is reminiscent of Bodin's reference to musical harmony in relation to a royal monarchy (Bodin, Six Bookes, p. 755 (lib. VI c. 6)). Alternatively, the reference to the 'descant' may be a response to Benn's argument (see note 109 above).

${ }^{133}$ Henry Robinson, Certaine proposals in order to a new modelling of the lawes and law-proceedings for a more speedy, cheap, and equall distribution of justice throughout the common-wealth (London: M. Simmons, 1653), p. 4 .
} 
about who or what was the supreme authority in Interregnum England. ${ }^{134}$ While it was possible to discuss equity and the Chancery without reference to questions of sovereignty, the influence of Bodin, perhaps via Lambarde (whose Archeion was printed in 1635) intertwined questions of equity with matters of prerogative and fundamental political authority. As the harmony of the commonweal gave way to discord in the mid-seventeenth century, the prerogative itself came to be challenged and criticised. The Chancery's existence came to be threatened by an association with the prerogative, an association which had protected the Chancery a few decades earlier.

\footnotetext{
${ }^{134}$ Anon, Considerations touching the dissolving or taking away the court of chancery and the courts of iustice depending upon it (London: Thomas Heath, 1653), p. 4.
} 